\title{
三軸部分圧縮強度試験におけるコンクリートの強度 \\ STRENGTH OF CONCRETE WITH TRIAXIAL COMPRESSION TESTS IN WHICH SPECIMENS WERE PARTIALY LOADED IN AXIAL DIRECTION
}

\author{
徳 富久二* \\ Hisashi TOKUTOMI
}

\begin{abstract}
Triaxial compression tests on concrete were performed. The specimens of the triaxial compression tests were partially loaded in the axial direction, and the fracture strength of the concrete was investigated. The experimental results were compared with the results of an analytical method proposed by the authors. The process of the analysis was as follows: The shapes of fracture in these tests were reverse truncated cones. The stress on the cone was dicided by Griffith's fracture criterion. The cone was inserted into the specimen, and the fracture mechanism began when the stress in the circumferential direction on the outside cone reached the tensile strength of the materials.

Experimental values generally agree with the analytical results. Therefore this study showes the strength of concrete is affected remarkably by Griffith's fracture criterion on the tensile strength of the materials.
\end{abstract}

keywords: Triaxial compression tests, Griffith's fracture criterion, Tensile strength, Reverse truncated cones 三軸圧縮試験、グリフィスの破壊基準、引張強度、逆円錐台

\section{1. はじめに}

コンクリートの破壊はコンクリート内部の亀裂進展による引張破 壊現象として捉えられ、今日では破壊に関する研究は、亀裂の進展、 その進展開放される歪エネルギーなど細部に瓦り展開され、多くの 知見が得られている。一方、コンクリート構造物を対象とした設計 レベルからコンクリートの破壊問題を考えるとき、破壊現象がこれ らに必ずしも実用的な意味から適用されているとは云い難い。

筆者等は、Griffithの破壊規準に基礎をおいた引張亀裂の進展を 表す量としての面濃度という物理量を提案してコンクリートの破壊 を解积しようとしてきた ${ }^{1)}$ 。また、南九州に特殊土壤として広く分 布するシラスの破壊を研究する過程で、側圧の作用下で軸方向に部 分生縮する強度試験(三軸部分圧縮試験と称す)を行って、シラスの ような弱熔結物質の破壊問題を別の角度から実験的に检討した経緯 がある2〉。前者は破壊過程について言及するものであり、後者は最 終崩壊について言及するものであった。

実験的に破壊条件を決定する三軸圧縮試験も共通の破壊基準に従 うものと考えられる。コンクリートの破壊条件を決定する三軸圧縮 試験も試験体の形状、寸法によって、その内部の応力状態が異なり 複合応力下の特定の破壊条件であると見ることができる。その元と しての破壊条件の存在について検討することを考える。三軸部分圧 縮試験は、試験体の周囲に側圧が作用する状態において、一般に行 われる三軸圧縮試験の軸方向を部分圧縮する実験であり、部分圧縮 の条件をかえて実驗するとき、その結果は共通する破壊基準に支配 されていると考えるものである。本報告は、三軸部分圧縮試験の解 析過程をコンクリートについて適用・実験し、その解析過程におい
て Griffith の破壊基準に基䃈をおいた立場から検討したものであ る。また、本研究は、破壊力学における古典的手法であり、コンク リートのような脆性材料に Griffith の理論を適用する研究はこれ までにかなり行われているものの、その理論を実験的あるいは解析 的に研究し、実用的適用について再度考察し、研究することも必要 であると考えて行ったものである。

\section{2. 三軸部分任縮状態の解析}

コンクリートの強度試験において、破壊が引張裂け破壊過程を伴 う現象であることを窺うことができる。破壊条件を調べる三軸圧縮 試験は、崩壊した最終状態に着目するものであって、この結果も供 試体内部における応力状態と破壊基準によって決まってくるものと 考えられる。このように供試体内部の要素の各点の破壊に着目する とき、通常の三軸試験の結果から破壊基準を導き出すことは不可能 である。

側圧の作用下において、通常の三軸圧縮試験の軸方向を部分圧縮 する試験を行って、部分圧縮の割合(載荷率)を変えて実験を行うと き、これらに共通する条件が存在するものと考える。部分圧縮の載 荷率とは供試体全面に載荷する試験における載荷面に対する部分的 に載荷する試験の載荷面の割合のことをいい、それそれの直径の此 （載荷面の直径／供試体の直径)で表すことにする。通常の三軸圧縮 試験では供試体直径 $10 \mathrm{~cm}$ で載荷面の直径が10 cmであるので、載荷率 を 10/10と表す。この載荷率を変えて実験するとき、これらに共通 する破壊基準が存在し、この元になる条件が破壊基準と見るもので ある。ここでは、三軸部分圧縮状態の解析について述べ。 


\section{1 崩壊形と解析仮定}

部分任縮する場合の崩壊形は、䇝荷板下でくさびが形成され、こ れが圧入するように崩壊することが、シラスやコンクリートの実験 から推測される。写真-1は今回の実験における一般的崩壊形状であ る。写真右は左部分の崩壊した箇所を取りたししもので、写真左よ りおよその崩壊形状が判る。くさびが上下に形成され、それらが互 いに相貫するように形成されることが見られる。崩壊の形状は、く さび周辺と載荷板中央から放射状に伸びる数本の亀裂であり、その 亀裂は写真(写真上部)に示すように3〜4本で、くさびの外部におい て上下に連続する。

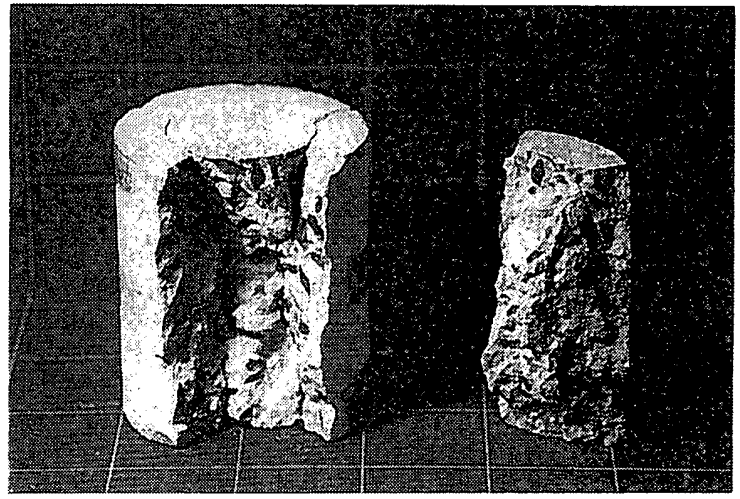

写真-1 三軸部分圧縮試験によるコンクリート試験体の崩壊状況

このような破壊形状を元に、図-1に示すようなくさびが形成され るものとする。困は試験体の $1 / 4$ 部分について示すものである。崩 壊する状態における力の釣合は、くさび部分の釣合とその周辺部の 釣合とから考えられる。

解析の仮定として、実験した崩壊形を理想化して次のように仮定 する。厳密には仮定した応力には、応力の分布が存在することも考 えられるが、その根抛を持たないため以下のように仮定する。

a）上下の載荷板の下に形成されるくさびの形状を逆円錐台状とし、 これに一様の垂直応力 $(\sigma)$ とせん断応力 $(\tau)$ が作用するものとす る。

b）くさびに作用する載荷板からの荷重をPとし、一様な分布力 $(p)$ が作用するものとする。

c）くさびの底面 $\left(\mathrm{B}^{\prime} D^{\prime}\right)$ に作用する反力を $\mathrm{F}_{\mathrm{c}}$ として、これも一様に 分布する $\left(f_{c}\right)$ ものとする。

d) くさび外側の台形(CDD’ C') 部分は、円周方向に引張応力を生じ る。

くさびを形成する境界における垂直応力 $(\sigma)$ とせん断応力 $(\tau)$ の 関係をくさび形成条件と呼ぶこととする。このくさび形成条件は不 明であるが、くさびは奧体的に圧入することが考えられる。載荷率 を変えた実験を行うとき、双方の結果から共通のくさび形成条件を 求めることができが、本報告では後で述べるように Griffith の 基準をくさび形成条件として採用した。

\section{2 解析}

図-2はくさび部分の力の作用方向および寸法関係を示すものであ

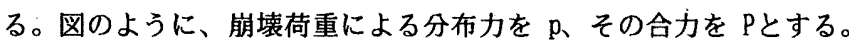
またくさび同士の交差部分(逆円錐台下部)に作用する分布力を $\mathrm{f}_{\mathrm{c}}$ と

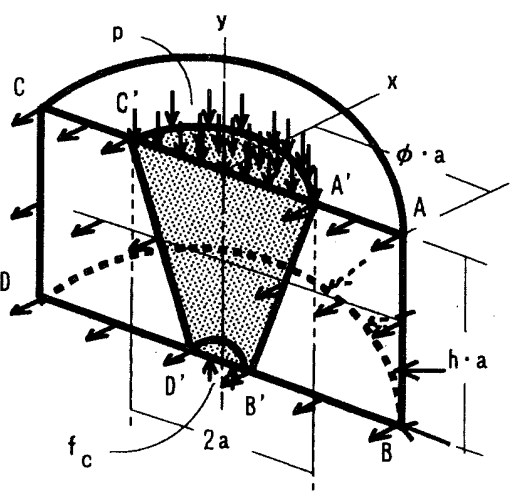

図-1三軸部分王縮状態のくさび形成と力の釣合

し、その合力を $\mathrm{F}_{\mathrm{c}}$ とする。くさび部分に作用する垂直応力 $(\sigma)$ とせ ん断応力 $(\tau)$ の 方向成分を $\mathrm{f} f(\sigma, \tau)$ とする。くさび部分に作用 する垂直応力 $(\sigma)$ とせん断応力 $(\tau)$ の分布における一様性の保証は ないか、、平均化した垂直応力とせん断応力と考えて解析する。

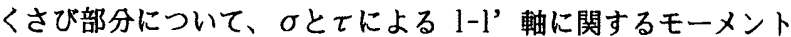
を求める。図のように、載荷板の半径をa、供試体の半径を $\phi \mathrm{a} 、$ 供試 体の高さを 2ha とする。くさび形成位置(図のA'B'の延長とl-l’軸 の交点)が載荷面からb・aの距離にあるものとしてbをくさび形成位 置と呼ふことにすると、y の位置で、微小部分ds に作用する力 $\left.{ }_{\mathrm{y}} \mathrm{f}(\sigma, \tau)\right)$ を求める。図のように、 $\sigma, \tau$ よる斿向の力を $\mathrm{y} f(\sigma$, て)とするとき、

$$
{ }_{\mathrm{y}} \mathrm{f}(\sigma, \tau)=\sigma \cdot \sin \alpha+\tau \cdot \cos \alpha
$$

であり、この力が半円周に作用し、またこの力の重心は、1-1'軸か らの距離を $\mathrm{X}_{\mathrm{g}}$ とし、半径を $\mathrm{r}$ とするとき、

$X_{B}=2 r / \pi$
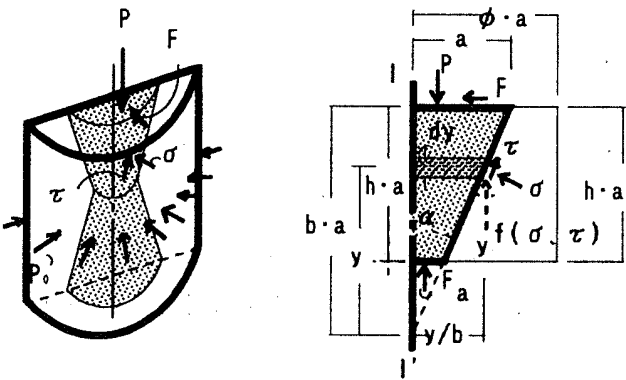

図-2 くさび部分の力の釣合および記号

てあり、微小部分 $\mathrm{ds}$ に作用する力 $\left(\Delta_{\mathrm{y}} \mathrm{f}(\sigma, \tau)\right)$ は、円周方向の長 さ $\pi \cdot \mathrm{y} / \mathrm{b}$ を乗じて

$$
\Delta_{y} f(\sigma, \tau)={ }_{y} f(\sigma, \tau) \cdot \mathrm{ds} \cdot \pi \cdot \mathrm{y} / \mathrm{b}
$$

で与えられる。ds に作用する l-l' 軸のモーメント $(\Delta \mathrm{y} M(\sigma, \tau))$ は、 $\mathrm{ds}=\mathrm{dy} / \cos \alpha$ と（2)、（3)式により

$$
\Delta_{\mathrm{y}} \mathrm{M}(\sigma, \tau)=-2 \cdot{ }_{\mathrm{y}} \mathrm{f}(\sigma, \tau) \cdot \mathrm{dy} / \cos \alpha \cdot \mathrm{y}^{2} / \mathrm{b}^{2} \cdots(4)
$$

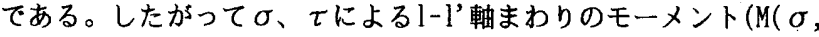


$\tau)$ 浐

$$
\begin{aligned}
M(\sigma, \tau) & =-\int \Delta_{y} M(\sigma, \tau) \\
= & -2 \cdot{ }_{y} f(\sigma, \tau) /\left(b^{2} \cdot \cos \alpha\right) \cdot \int_{(b-h) a}^{b a} \quad y^{2} \cdot d y \\
\equiv & \overline{A A} \cdot{ }_{y} f(\sigma, \tau) \\
& \quad \overline{A A}=-2 / 3 \cdot(a / b)^{3} \cdot\left(b^{3}-(b-h)^{3}\right) \cdot\left(1+b^{2}\right)
\end{aligned}
$$

つきに、半径 r の半円に作用する垂直分布荷重度 $(p)$ の重心位置は、 l-1’軸からの距離 y として

$$
y=4 r /(3 \pi)
$$

したがって、分布荷重度 $(\mathrm{p})$ によるl-l’軸まわりのモーメント $\left(\mathrm{M}_{\mathrm{p}}\right)$ は、

$$
\begin{gathered}
M_{p}=p / 2 \cdot \pi \cdot a^{2} \cdot 4 a /(3 \pi) \equiv \overline{B B} \cdot p \\
\overline{B B}=2 a^{3} / 3
\end{gathered}
$$

で与えられる。同様に、 $f_{c} に よ る ~ l-l ’$ 軸まわりのモーメント $\left(M_{\mathrm{fc}}\right)$ は、

$$
\begin{gathered}
M_{\mathrm{fc}}=-2 / 3 \cdot(b-h)^{3} \cdot \mathrm{a}^{3} / \mathrm{b}^{3} \cdot \mathrm{f}_{\mathrm{c}} \equiv \overline{\mathrm{CC}} \cdot \mathrm{f}_{\mathrm{c}} \\
\overline{\mathrm{CC}}=-2 / 3 \cdot(\mathrm{b}-\mathrm{h})^{3} \cdot(\mathrm{a} / \mathrm{b})^{3}
\end{gathered}
$$

式(5)、（7)、（8）よりモーメントの釣合は、

$$
\overline{\mathrm{AA}} \cdot{ }_{\mathrm{y}} \mathrm{f}(\sigma, \tau)+\overline{\mathrm{BB}} \cdot \mathrm{p}+\overline{\mathrm{CC}} \cdot \mathrm{f}_{\mathrm{c}}=0
$$

である。

軸方向の力の釣合をクサビ部分について求めると、 $\mathrm{p}$ による荷重 $\left(F_{p}\right)$ は、

$$
\begin{gathered}
F_{p}=-1 / 2 \cdot p \cdot \pi \cdot a^{2} \equiv \overline{D D} \cdot p \\
\overline{D D}=-1 / 2 \cdot \pi \cdot a^{2}
\end{gathered}
$$

$\sigma 、 \tau$ による力 $(F(\sigma, \tau))$ は、

$$
\begin{aligned}
\mathrm{F}(\sigma, \tau) & =\iint_{(\mathrm{b}-\mathrm{h}) \mathrm{a}}^{\mathrm{ba}} \mathrm{y} f(\sigma, \tau) \cdot \mathrm{ds} \cdot \pi \cdot \mathrm{y} / \mathrm{b} \\
& \equiv \overline{\mathrm{EE}} \cdot{ }_{\mathrm{y}} \mathrm{f}(\sigma, \tau) \\
\overline{\mathrm{EE}} & =1 / 2 \cdot \pi \cdot h \cdot(\mathrm{a} / \mathrm{b})^{2} \cdot(2 \mathrm{~b}-\mathrm{h}) \cdot\left(1+\mathrm{b}^{2}\right)
\end{aligned}
$$

$f_{c}$ による力 $\left(F_{f c}\right)$ は、

$$
\begin{gathered}
F_{f c}=f_{c} \cdot 1 / 2 \cdot \pi(a / b)^{2} \cdot(b-h)^{2} \equiv \overline{F F} \cdot f_{c} \\
\overline{F F}=1 / 2 \cdot \pi \cdot(a / b)^{2} \cdot(b-h)^{2}
\end{gathered}
$$

したがって、y 方向の力の釣合は、式(10)、(11)、(12)より、

$$
\overline{\mathrm{DD}} \cdot \mathrm{p}+\overline{\mathrm{EE}} \cdot{ }_{\mathrm{y}} \mathrm{f}(\sigma, \tau)+\overline{\mathrm{FF}} \cdot \mathrm{f}_{\mathrm{c}}=0
$$

式(9)および(13)より $\mathrm{f}_{\mathrm{c}}$ を消去して、 となる。

$$
\mathrm{p}=(\overline{\mathrm{CC}} \cdot \overline{\mathrm{EE}}-\overline{\mathrm{FF}} \cdot \overline{\mathrm{AA}}) /(\overline{\mathrm{BB}} \cdot \overline{\mathrm{FF}}-\overline{\mathrm{CC}} \cdot \overline{\mathrm{DD}}) \cdot{ }_{\mathrm{y}} \mathrm{f}(\sigma, \tau)
$$

つぎに、くさび周辺部の力の釣合について考える。
図-3はくさび周辺部の力の作用方向・釣合関係を示す。半径方向の 力の釣合について考える。くさび斜面上の応力 $(\sigma, \tau)$ にる $\mathrm{x}$ 方 向の応力を $\times f(\sigma, \tau)$ とすると、

$$
{ }_{\mathrm{x}} \mathrm{f}(\sigma, \tau)=\sigma \cdot \cos \alpha-\tau \cdot \sin \alpha
$$

図-3に示すように、半径方向に $\mathrm{x} f(\sigma, \tau) 、 \mathrm{P}_{0}($ 側圧)が作用する。 これらを $\mathrm{f}$ として表すと、半径 $\mathrm{r}$ における合力は $2 \cdot \mathrm{f} \cdot \mathrm{r}$ であり、 ${ }_{\times} \mathrm{f}(\sigma, \tau)$ による半径方向の合力 $(\mathrm{R}(\sigma, \tau))$ は、

$$
\begin{aligned}
\mathrm{R}(\sigma, \tau) & =\iint_{(\mathrm{b}-\mathrm{h}) \mathrm{a}}^{\mathrm{ba}} 2 \cdot \mathrm{f}(\sigma, \tau) \cdot \mathrm{y} / \mathrm{b} \cdot \mathrm{d} \mathrm{s} \\
& \equiv \overline{\mathrm{GG}} \cdot \sigma+\overline{\mathrm{HH}} \cdot \tau
\end{aligned}
$$

$$
\overline{\mathrm{GG}}=h \cdot \mathrm{a}^{2} / \mathrm{b} \cdot(2 \mathrm{~b}-\mathrm{h}), \quad \overline{\mathrm{HH}}=-\mathrm{h} \cdot(\mathrm{a} / \mathrm{b})^{2} \cdot(2 \mathrm{~b}-\mathrm{h})
$$

となる。

同様に、側圧 $\left(\mathrm{P}_{0}\right)$ による半径方向の力 $\left(\mathrm{R}_{\mathrm{P} 0}\right)$ は、

$$
\begin{gathered}
\mathrm{R}_{\mathrm{P} O}=-\int_{0}^{\pi} \mathrm{P}_{0} \cdot h \cdot \mathrm{a}^{2} \cdot \phi \cdot \cos \theta \cdot d \theta \equiv \overline{\mathrm{II}} \\
\overline{\mathrm{II}}=-2 \cdot h \cdot \mathrm{a}^{2} \cdot \phi \cdot \mathrm{P}_{0}
\end{gathered}
$$

つきに、図-3 a)の台形AIJC、BLKD部分には引張応力が働くことが

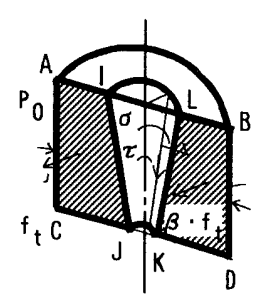

a)

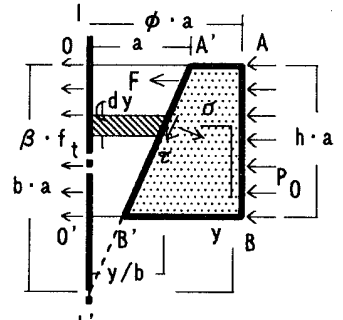

b)
図-3 くさび周辺部の力の釣合および記号

写真-1の崩壊形から考えられる。この引張応力は、図-3 b) におい て、 $\beta \cdot \mathrm{ft}$ の作用する応力による力としてくさび周辺部において釣 り合う。この合力 $\left(\mathrm{R}_{\mathrm{ft}}\right)$ は、図-3 のa)の斜線部の面積にたいして引 張強度 $\left(\mathrm{f}_{\mathrm{t}}\right)$ の $\beta$ 倍の応力が平均的に作用するとして、以下のように 求めておく。これはこの部分の引張応力が試験条件によって変化す る場合を想定するものである。

$$
\begin{aligned}
R_{f t}= & -2 \cdot h \cdot a^{2} \cdot(\phi-1+h /(2 b)) \cdot \beta f_{t} \\
\equiv & \overline{J J} \cdot f_{t} \\
& \overline{J J}=-2 \cdot h \cdot a^{2} \cdot(\phi-1+h /(2 b)) \cdot \beta
\end{aligned}
$$

コンクリートと載荷板との摩擦力を考える。荷重の初期段階では、 くさび部分の水平方向のつりあいは、図-3 a) の円錐台のIJKLの台 形部分にくさび円錐台斜面の垂直応力 $(\sigma)$ とせん断応力 $(\tau)$ の水平 成分とつりあう圧縮応力が作用して釣り合っている。後述するよう に、コンクリートと載荷板の摩擦力は、コンクリート試験体が荷重 の增大によって、半径方向の変位に対してこれを拘束するように発 生するものと考える摩擦力である。したがって、くさび部分につい て考えるとき、摩擦力に釣合う水平方向の力は、くさび部分に作用 
する水平力と釣り合う。この場合実際は斜面上の垂直応力とせん断 応力として作用し、その水平合力が摩摖力と釣り合うと考えられる。 このように、実際は摩擦力の存在しないときの応力と摩摖力による 応力の和として存在するものであるが、ここでは分離して考える。 同時にこれは、くさび周辺部へ影響し、くさび周辺部への水平力と して作用する。

負の方向に同一の力の作用として、この摩擦力をFとして、

$$
\overline{\mathrm{KK}}=-\mathrm{F}
$$

とする。これら式(17)、(18)、(19)、(20)より、くさび周辺部の力 のつりあいは、

$$
\overline{\mathrm{GG}} \cdot \sigma+\overline{\mathrm{HH}} \cdot \tau+\overline{\mathrm{II}}+\overline{\mathrm{JJ}}+\overline{\mathrm{KK}}=0
$$

となる。

くさび形成条件は載荷率を変化させた実験から求められるものて あるが、ここでは破壊基準式を予め想定して解析する。コンクリー 卜の破壊に引張破壊が大きく寄与するものであるとするとき、引張 破壊基準として広く知られる Griffith の破壊基準との関係から推 定することが考えられる。Griffithの破壊基準は偏平棈円クラック に応力が集中したときの引張破壊条件として求められたものて、材 料内の一点がこの条件となる場合の条件であると捉えることができ、 ガラスのように極端な脆性を示す材料では一点の破壊が終局破壊に 到達し、Griffithの破壊基準と崩壊荷重が適合するが、コンクリー トのような材料では、一点の破壊によって系全体の破壊に至ること はない。ここでは、Griffithの破壊基準を修正して、つきのように くさび形成条件として表す。引張強度を $\mathrm{f}_{\mathrm{t}}$ 、脆性度による修正係数 $\mathrm{k}_{\mathrm{G}}$ を導入して、また本解析における符号を考慮すると、

$$
\tau^{2}=4 \cdot k_{G} \cdot f_{t} \cdot\left(\sigma+f_{t}\right)
$$

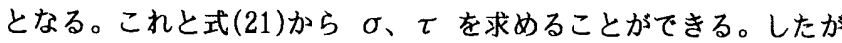
って、式(14)は、yf $(\sigma, \tau)$ を書き換えて、

$\mathrm{p}=(\overline{\mathrm{CC}} \cdot \overline{\mathrm{EE}}-\overline{\mathrm{FF}} \cdot \overline{\mathrm{AA}}) /(\overline{\mathrm{BB}} \cdot \overline{\mathrm{FF}}-\overline{\mathrm{CC}} \cdot \overline{\mathrm{DD}}) \cdot(\sigma \cdot \sin \alpha+\tau \cdot \cos \alpha) \cdots(22)$

となり、 $\sigma 、 \tau$ を代入して軸方向応力度 $(\mathrm{p})$ を求めることができる。

くさび形成位膡 $(\mathrm{b})$ を種々に変化させ、鉛直荷重度 $(\mathrm{p})$ を計算する とき、各くさび形成位置によって崩壊荷重が計算される。計算され た崩壊荷重 $\mathrm{p}$ の最小值が、求める崩壊荷重となる。このことにより、 崩壊荷重は引張強度によって定義できることになる。

\section{§3．コンクリートの三軸部分圧縮試験}

三軸部分圧縮装置を設計・製作して、軸方向載荷面積を変化さ せた三軸部分圧縮試験をコンクリートについて実施した。

\section{1 使用材料と試験体の作製}

使用材料は表-1に示す一般的コンクリート 1 種類について同時に 全試験体を作製して、变動を極力避けようとするものである。

供試体は図-4 に示すように、3種類である。供試体は直径 $10 \mathrm{~cm}$ する円柱であり、図のように高さが異なる。図の塗りつぶした部分
は部分圧縮部である。供試体の高さは載荷部分の直径の 2倍の寸法 とする。図-4 a) は部分載荷率 $(\gamma$ : 載荷部分の直径/試験体直径)か3 10/10、図-4 b) は $\gamma=8 / 10 、$ 図4 c)は $\gamma=6 / 10$ であるので、高さを

\begin{tabular}{|c|c|c|c|c|c|c|}
\hline $\begin{array}{l}37^{\circ} \\
\mathrm{cm})\end{array}$ & $\begin{array}{r}\text { 水比 } \\
(\%)\end{array}$ & $\begin{array}{c}\text { 水 } \\
(\mathrm{kg})\end{array}$ & $\begin{array}{l}\text { セメト } \\
\text { (kg) }\end{array}$ & $\begin{array}{c}\text { 細骨材 } \\
(\mathrm{kg})\end{array}$ & $\begin{array}{c}\text { 粗＼cjkstart骨材 } \\
(\mathrm{kg})\end{array}$ & $\begin{array}{c}\text { 空気量 } \\
(\%)\end{array}$ \\
\hline 18 & 65 & 195 & 300 & 759 & 998 & 4 \\
\hline
\end{tabular}
それそれ20、16、12cmとするものである。図には供試体への側圧と 軸圧としての荷重の作用方向を矢印で模式的に示している。

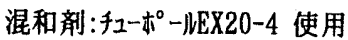

供試体数は4試験条件につき各3個の合計12個づつ、総計36個と割 裂引張試験用の供試体15個の計51本と予備の供試体である。コンク リートの条件を均一にするため、生コンにより一気に打設した。コ ンクリート打設後24時間室内放置したのちに脱型し、35日間水中養 生 $\left(20 \pm 1^{\circ} \mathrm{C}\right)$ を行う。その後養生室内に空中放置した。

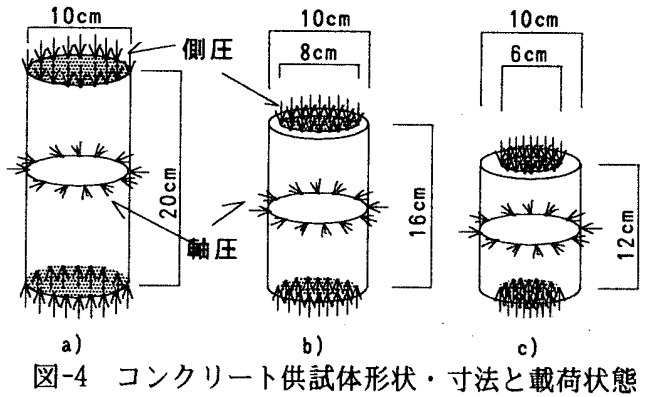

\section{2 実験方法}

割裂引張試験は、JIS A1113による引張強度試験方法によった。三 軸部分圧縮試験との対応を見る目的をもつので三軸部分王縮試験を 行った材令の試験体について強度試験を行った。

図- 5 は、三軸部分圧縮試験装置の概要を示す。試験装置は三軸 室、側圧装置、軸圧装置の三部分よりなる。エヤーハイドロブース ターによってウオーターリザーバーの水を高側圧化して三軸圧縮室 に導入することができる。軸方向載荷装置はアムスラー型圷縮試験 装置である。

三軸部分圧縮室は、図-6 に示す装置を設計・製作した。この装置 は供試体(図のA、B)に載荷棒からの軸力を部分載荷板を通して作用 させる。Aは部分載荷率が10/10の全面載荷状態の試験を、Bは部分載 荷率が8/10の部分載荷状態を示す。Bの部分載荷試験は部分載荷板が スライドするCとDの部分に分かれている。この状態を右図に拡大し て示す。部分載荷率に応じて載荷板が異なることはもちろん、載荷 板ガイドも変化し、これらを含めた載荷治具の直径は供試体の直径 となる。

供試体と載荷治具のガイド部全体にゴムスリーブを被せて水漏れ を防ぐ硬質ゴム輪で固定する。

実験順序は、供試体をセットした三軸圧縮室を軸方向載荷装置で ある耐圧試験機に設置する。徐々に側圧を作用させるがその側圧と 


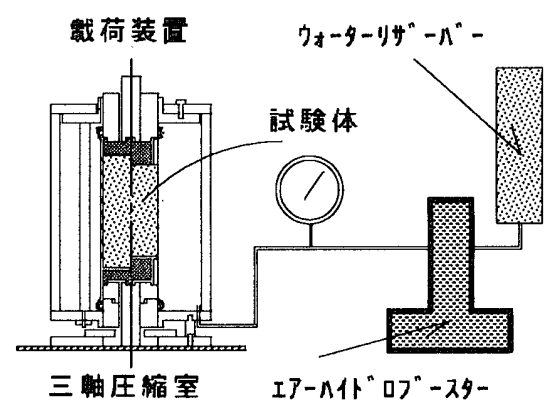

図- 5 三軸部分圧縮試験装置全体図

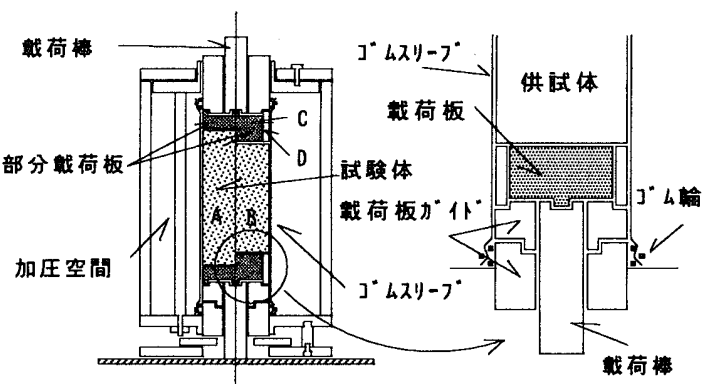

図- 6 三軸部分圧縮室
表- 3 三軸部分圧縮強度試験の崩壊荷重度 $\left(\mathrm{kg} / \mathrm{cm}^{2}\right)$

\begin{tabular}{c|c|c|c|c|c}
\hline \multirow{2}{*}{$\gamma$} & \multirow{2}{*}{ No } & \multicolumn{4}{|c}{ 側圧 $\left(\mathrm{kg} / \mathrm{cm}^{2}\right)$} \\
\cline { 3 - 6 } & & 0 & 20 & 40 & 60 \\
\hline \multirow{3}{*}{$6 / 10$} & 1 & 391.4 & 813.5 & 753.3 & - \\
& 2 & 433.9 & 834.7 & 753.3 & - \\
& 3 & 534.1 & 642.5 & 699.6 & 900.7 \\
\hline \multirow{3}{*}{$8 / 10$} & 1 & 397.2 & 535.2 & & 716.2 \\
& 2 & 423.8 & 547.1 & 599.5 & 771.2 \\
\hline \multirow{3}{*}{$10 / 10$} & 3 & 293.8 & 608.1 & 635.3 & \\
\hline & 1 & 247.9 & 318.7 & 396.8 & 472.8 \\
& 3 & 215.2 & 473.7 & 424.8 & 506.8 \\
\hline
\end{tabular}

図中に示すように直線で近似して、 $\mathrm{p}$ を崩壊荷重、Poを側圧とする と以下のようになる。

$$
\begin{aligned}
& \gamma=10 / 10 \text { で } \quad \mathrm{p}=3.61 \times \mathrm{P}_{0}+275\left(\mathrm{~kg} / \mathrm{cm}^{2}\right) \\
& 8 / 10 \text { " } \mathrm{p}=5.94 \times \mathrm{P}_{0}+398\left(\mathrm{~kg} / \mathrm{cm}^{2}\right) \\
& 6 / 10 / p=6.76 \times P_{0}+514\left(\mathrm{~kg} / \mathrm{cm}^{2}\right)
\end{aligned}
$$

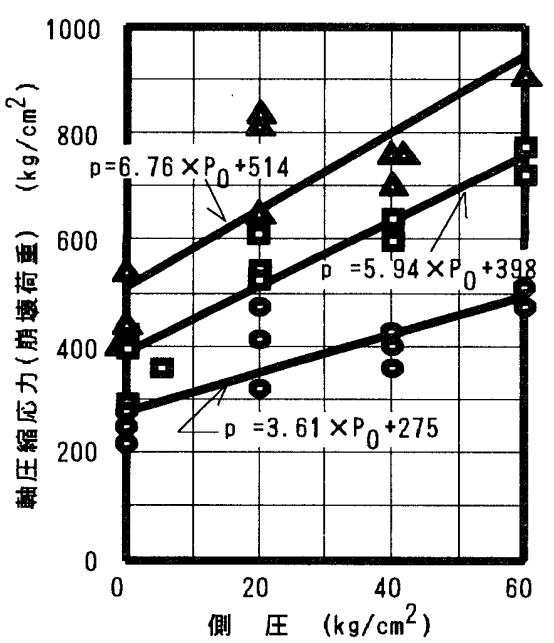

図- 7 三軸部分圧縮強度試験の結果

§4.コンクリートと載荷板の摩擦力

シラス供試体における三軸部分載荷実験では、シラスと載荷板の 接触による摩擦力が崩壊荷重に与える影響は相対的に小さく、摩擦 力が問題になることはなかった。しかしながら、コンクリート供試 体ではこの摩摖力が崩壊荷重に影響し、意味を持つようになると考 えられる。ここでは解析に用いる載荷板とコンクリートとの摩擦力 について㛟討する。

\section{1 摩擦力の合力}

コンクリートの三軸部分圧縮強度の解析にあたって必要とする摩 擦力は、載荷板中心方向に作用する摩擦力 $(\mathrm{F})$ を求めることである。 単位面積あたりの摩擦力が、半径方向に比例すると仮定するとき、 半径方向 $\mathrm{r}$ の位置では摩擦応力が $\mathrm{k} \cdot \mathrm{r}$ で表されるとすると、図-8 のように微小部分について 


$$
\mathrm{F}=2 \cdot \mathrm{S}_{0}^{\pi / 2} \mathrm{~S}_{0}^{\mathrm{a}} \mathrm{kr} \cdot \mathrm{dr} \cdot \mathrm{r} \cdot \mathrm{d} \theta \cdot \cos \theta=2 / 3 \cdot \mathrm{k} \cdot \mathrm{a}^{3} \cdots(23)
$$

で与えられる。

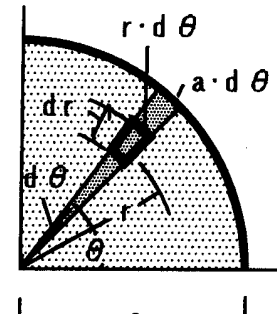

比例定数 kは、載荷板に 作用する垂直応力によって 変化する。載荷板に作用す る垂直応力と摩擦力の関係 を、有限要素法によって求 める。困- 9 のような要素 数を280、節点数を 165 とす る要素分割によって求める。 摩擦力の算定には一定の垂

図-8. 摩擦力の合力

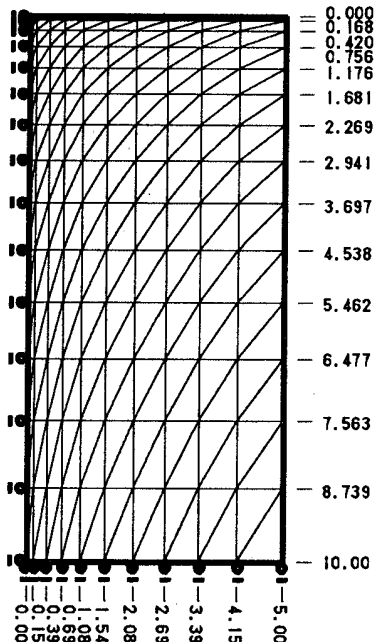

図- 9. 有限要素分割

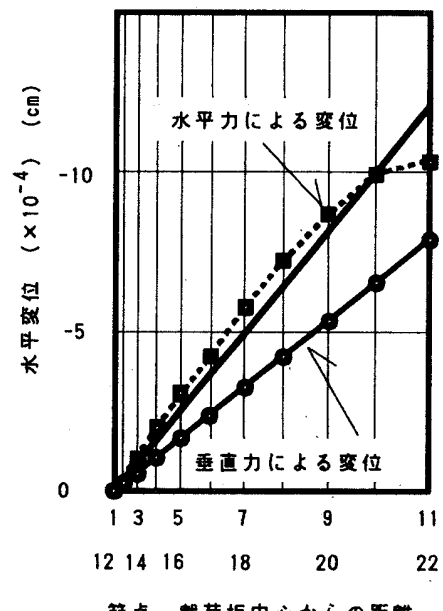

図-10 F.E.M解析による垂直、水平応力作用下の水平変位

合には図のように載荷板周辺の変位が比例関係にあることが判る。 一方、中心から比例した水平力を作用させた場合の水平変位は図の ように、載荷板周辺の変位が比例関係から逸脱するが、これもほほ 比例するものとみなして解析した。節点 9,20 の垂直応力による変 量と、半径方向に比例する 水平荷重を作用させたとき の水平変位を等置すること によって摩擦力を評価する ものである。

図-10 は垂直荷重と水平 荷重の作用下における水平 変位を表したものである。 垂直荷重は $100 \mathrm{~kg} / \mathrm{cm}^{2}$ の分 布荷重を、水平荷重は $10 \mathrm{k}$ $\mathrm{g} / \mathrm{cm}^{2} / \mathrm{cm}$ の中心から比例し た荷重を作用させたもので ある。F.E.M弾性解析にお ける水平変位 は $100 \mathrm{~kg} / \mathrm{cm}^{2}$ の垂直応力を作用させた場
位は、 $5.49 \times 10^{-4} \mathrm{~cm}$ であり、点線の節点 $9 、 20$ の変位は $9.47 \times 10^{-4}$ c⿴囗十゙ある。したがって、100 ×9.47/5.49( $\left.\mathrm{kg} / \mathrm{cm}^{2}\right)$ の垂 直応力作用 の下での変位が $10 \mathrm{~kg} / \mathrm{cm}^{2} / \mathrm{cm}$ の心から比例する水平応力作用下の 水平変位と等価である。これを、 $\mathrm{q}\left(\mathrm{kg} / \mathrm{cm}^{2}\right)$ の垂直応力作用の場合 に換算すると、

$$
10 \mathrm{q} /(100 \times 9.47 / 5.49)=0.0580 \cdot \mathrm{q}=\mathrm{k}
$$

となり、摩擦力 $(F) は$

$$
\begin{aligned}
& F=2 / 3 \cdot \mathrm{k} \cdot \mathrm{a}^{3} \\
&=2 / 3 \cdot \mathrm{a}^{3} \times 0.0580 \times \mathrm{q} \quad(\mathrm{kg}) \\
& \text { ここに、 } \mathrm{a}: \text { 円形載荷板の半径 }(\mathrm{cm}) \\
& \mathrm{q}: \text { 載荷板に作用する垂直応力 }
\end{aligned}
$$

となる。

\section{§5. 実験結果の検討}

三軸部分王縮試験の解析過程を使用して、実験結果を検討する。

\section{1 実験結果と計算結果の比較}

計算仮定は、くさび形成条件としてGriffithの破壊基準を導入す ることと、コンクリート供武体と載荷板の摩擦力を考虑することで ある。これまでのシラスの解析では実験によってくさび形成条件を 決定するものであり、また供試体と載荷板の摩擦力は無視していた。 くさび形成条件として、実験から求められる新たな提案も考えられ るか、既にある破壊基準を適用し検証することが必要である。ここ では新たに、基準を求めるものでなくGriffithの破壊基準をくさび 形成条件に導入して検討した。また、Griffithの破壊基準は引張破 壊から求められた基準であるので、引張破壊で統一されることにな ることも導入の契機である。

Griffithの破壊基準の導入とは、(20)式の垂直応力 $(\sigma)$ とせん断

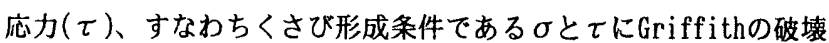
基準式(21)を適用するもので、再揭すると

$$
\begin{aligned}
& \overline{\mathrm{GG}} \cdot \sigma+\overline{\mathrm{HH}} \cdot \tau+\overline{\mathrm{II}}+\overline{\mathrm{JJ}}+\overline{\mathrm{KK}}=0 \\
& \tau^{2}=4 \cdot \mathrm{K}_{\mathrm{G}} \cdot \mathrm{f}_{\mathrm{t}} \cdot\left(\sigma+\mathrm{f}_{\mathrm{t}}\right)
\end{aligned}
$$

から、ここに Griffith 式の符合は解析の符合を採るものである。 これらの式よりくさびを形成する条件の $\sigma$ とてを求める。(21)式は 材料によって異なる修正係数としてKGを導入してあるが、本報告の 解析では $\mathrm{K}_{\mathrm{G}}=1.0 と し て G r i f f t h$ 式そのものを使用した。

計算方法は所定の載荷条件(供試体形状、载荷率)、引張強度、摩 擦係数、側圧を特定するとき、くさび形成位置(b)を仮に設定し、は じめにコンクリートと載荷板の摩擦力が働かないものとして垂直力 (q)を求める。つきの段階からは、計算された垂直力 $(q) に$ 相当する摩 摖力が偟くとして、垂直力 (q)を算出する。この操作を繰り返し、く さび形成位置における収束した垂直応力を求める。くさび形成位置 (b)を変化させqを計算したとき、q の極小值が䡋荷条件における崩 壊荷重となる。

\section{2 三軸部分圧縮試験結果について}

解析は、引張強度のみによって崩壊荷重が決まるものである。し たがってコンクリートの三軸部分壬縮試験の結果は引張強度が特定 
されると各側圧毎の崩壊荷重を求めることができ、試験結果と比較 できる。一方解析過程では、くさび周辺部の台形部分に作用する引 張強度の分布を一様に仮定している。くさび周辺部の力のつりあい に関しては、半径方向のつりあいのみを取り扱っているので、分布 が一様でない場合は式(18)のように $\beta \cdot \mathrm{f}_{\mathrm{t}}$ に表れる。しかしながら、 この係数はくさびの形成位置によって変化するものであるため一義 的に決めることができない。図-11は、側圧が引張強度の5倍まで変 化するときの $\beta$ の変化に伴ってくさび形成位置の変化の様子を示す。

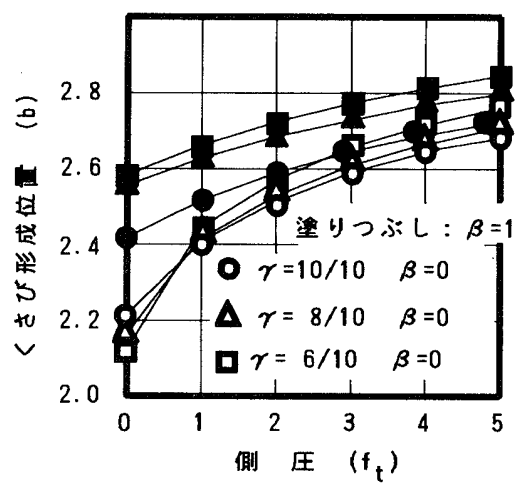

図-11 側圧、 $\beta$ とくさび形成位置の関係

載荷率が $\gamma=10 / 10$ 場合では、側圧が0のとき、 $\beta$ が0から 1 範囲 でくさび形成位置は、2.0から2.2の範囲をとることが判る。大きく 変化するのは、載荷率が $\gamma=6 / 10$ 側圧が0の場合であり、 1.9 から 2.4 までの範囲を採る。

このような範囲のくさび形成位置をとるときの、くさび周辺部台 形部分の円周方向の応力を、図-12のような分割によるF.E.M解析に よって求め、此較検討した。図の陰影をした要素のヤング係数をそ の他の部分のヤング係数の1/10とした弾性解析である。

図は載荷率が $\gamma=10 / 10$ の場合であり、 $\gamma$ が8/10、6/10の場合は同 様の分割であるので省略する。このようにして計算された結果を図 -13に示す。

結果は載荷面からの距離に対する層ことの平均応力を表し、その 応力が最大值を採る応力を1として表すものである。 $\gamma$ が10/10では 載荷面近傍において最大引張応力を生じ、 $\gamma$ が6/10では最大引張応 力が生じる層は供試体の中心部となることが判る。バラッキがある ものの、同一載荷率においては、くさび形成位置によって極端に円 周方向応力が異なる結果となるとは判断されない。したがって、実 線のように、載荷率毎の平均值によって表すことにして、平均引張 応力を求め、 $\beta$ を求めた。
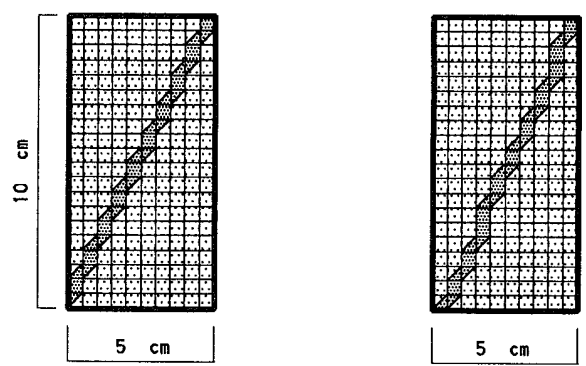

図-12 くさび形成位置の違いによる円周方向の解析

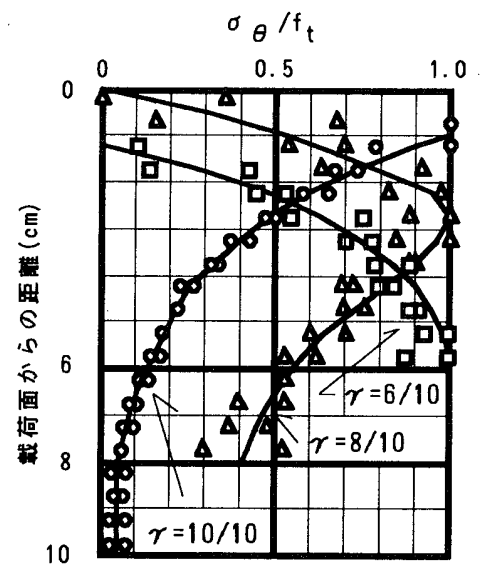

図-13 くさび周辺台形部の円周方向引張応力

解析過程はくさび周辺の円周方向台形部分が一様な引張強度に達 したとき破壊すると仮定するものであった。ここで匀等分布しない 場合は、最大の引張応力が引張強度に達するとき破壊が開始すると 考える。図-13 はこのような意味から計算された引張応力の最大值 を1として表現したものである。このとき平均引張応力は最大引張 応力の $\beta$ 倍として先の計算過程に組み込まれる。平均引張応力は台 形部分の面積を考慮した応力であり、これを求めると、 $\beta$ は $\gamma=10 / 10$ で0.13・f $\mathrm{f}_{\mathrm{t}} \gamma=8 / 10$ で $0.65 \cdot \mathrm{f}_{\mathrm{t}} 、 \gamma=6 / 10$ で $0.79 \cdot \mathrm{f}_{\mathrm{t}}$ となる。

また、この計算結果は $\gamma$ が6/10では載荷面付近に圧縮応力が生じ ている。計算過程は台形部分の面積を考虑しているので $0.79 \cdot \mathrm{f}_{\mathrm{t}}$ を 使用したとき、小さく評価されることになる。したがって、0.79を 台形の面積比に換算して、 $\beta$ を決定した。この場合は 0.89 となる。 同様に、 $\gamma$ が10/10の場合の0.13・ $\mathrm{f}_{\mathrm{t}}$ は大きく評価されていることに なる。この場合についても面積比で換算する。 $\gamma$ が10/10のときは換 算した結果は誤差範囲内であり、結果は変わらない。

結局、 $\beta$ は

$\begin{array}{rrr}\gamma=10 / 10 & \text { で } & 0.13 \cdot \mathrm{f}_{\mathrm{t}} \\ 8 / 10 & \text { "l } & 0.65 \cdot \mathrm{f}_{\mathrm{t}} \\ 6 / 10 & \text { "I } & 0.89 \cdot \mathrm{f}_{\mathrm{t}}\end{array}$

とする。

割裂引張強度は実験した平均強度が $27 \mathrm{~kg} / \mathrm{cm}^{2}$ である。 $\gamma$ が、10/10 の側圧 $0 \mathrm{~kg} / \mathrm{cm}^{2}$ のとき、これは圧縮強度に相当するものであり、平均 は $276 \mathrm{~kg} / \mathrm{cm}^{2}$ である。この圧縮強度と割裂引張強度を比較すると、引 張強度の数值が高い結果となっている。压縮強度が270 $280 \mathrm{~kg} / \mathrm{cm}^{2}$ の一般的な割裂引張強度は22 $26 \mathrm{~kg} / \mathrm{cm}^{2}$ であることから、解析に使 用した引張強度は 24 と $27 \mathrm{~kg} / \mathrm{cm}^{2}$ の2種類について解析した。

以上の仮定した数值を使用して、三軸部分圧縮強度における解析 過程によって各試験条件について計算する。

図-14はくさび形成位置(b)による、側圧毎の崩壊荷重の変化を図 示したものである。くさび形成位置は側圧の増大とともに增加する ことが判り、側圧が 0の場合でもくさび形成位置(b)は、2付近であ る。くさび形成位置が 2のとき、円錐状のくさびとなり、側圧の増 加によって、円錐台状になることが判る。これらの側圧毎の最小崩 壊荷重が求める荷重(強度)である。この例は $\gamma$ が10/10、引張強度を $24 \mathrm{~kg} / \mathrm{cm}^{2}$ としたときである。

このようにして試験条件、側圧毎の強度の結果を図-15に示す。実 


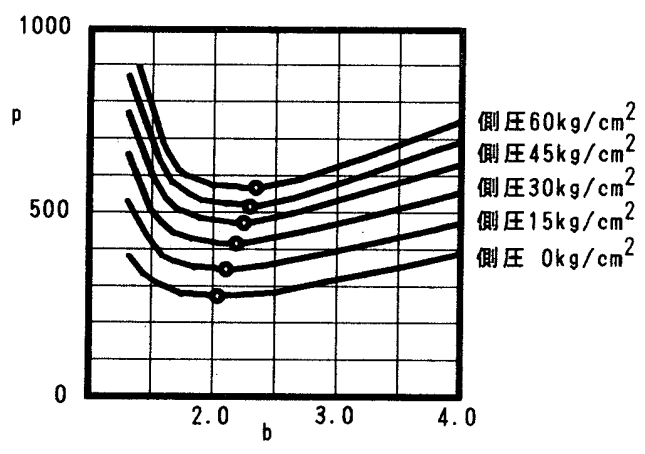

図-14くさび形成位娄 $(b)$ と崩壊荷重 $(p)$ の関係

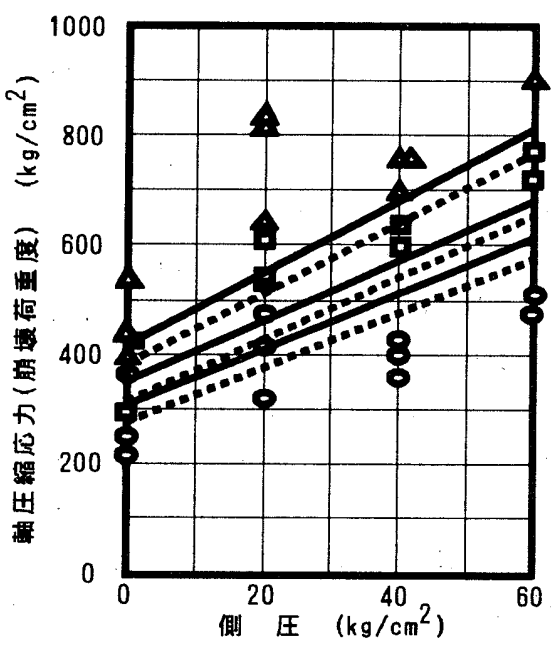

図-15 三軸部分圧縮強度試験の結果と計算結果

線が引張強度が $27 \mathrm{~kg} / \mathrm{cm}^{2} 、$ 点線が $24 \mathrm{~kg} / \mathrm{cm}^{2}$ の場合である。

$\gamma$ が8/10と6/10では解析值が実験值を下まわるように現れる。引 張強度の大小関係はそのまま解析值の大小関係となって現れること は当然の結果である。

図-16 は $\gamma=6 / 10$ のきの得られた実験結果から推定される、95\% 信頼限界であり、解析值は実線と点線で表される。解析值はおよそ 信頼限界内にあることが判る。すなわち、実験值のばらつきの状態 を考えるとき、解析值は実験值の母集団から出現していないと結論

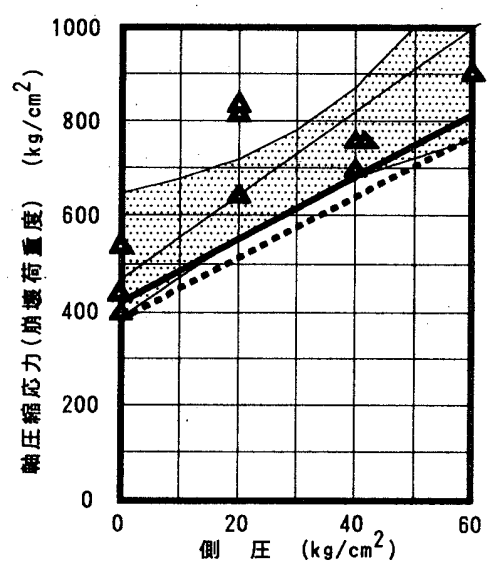

図-16 信頼限界 $(\gamma=6 / 10)$
づけることができない、棄却できないことを意味している。解析值 との差が大きい $\gamma=6 / 10$ におけるこの結果はその他のばらつきの少 ない試験条件の場合にはさらに良い適合度を示すものである。およ そ解析值が実験の範囲内ではあるが罗当なものであることを示す。

以上より、解析值と実験值がよく一致するものではないが、実験 值のばらつきを考慮するとおよそ解析值は実駼値を代表する傾向を 示すものと考えられる。

\section{§6. 結論}

シラスの破壊問題から発生した三軸部分王縮試験の解析過程をコ ンクリートの破壊、特に压縮強度に適用して考察した本報告は、コ ンクリートの破壊を引張強度に起因することに根拋をおいて解积し たものである。压縮試験体内部に生じるくさびの形成条件に Griff ith の破壊基準を導入して、周辺の拘束状態によって引張裂け破壊 による崩壊状態を定義して解析する、いわゆる引張強度のみに依存 した解析である。

くさびの圧入によるくさび周辺応力解析にあたって仮定したくさ びの形状、引張応力の分布など、多くの解析仮定を設けた解析であ るなど、厳密な適用とは云えないものの、これまでに述べた結果を 取りまとめ、その結果から発展して考えられることを示すと、

(1) 本研究はコンクリートにおける三軸部分圧縮試験を行って、解 析值と比較検討した。この結果、およそ解析值が実験值を代表する ものであると考えられる。

（2）またこのことは試験条件を変化させて実験を行い、破壊形状か らモデルを仮定して、Griffithの破壊条件を導入して解析したとき、 実験結果は解析結果から出現していることを棄却できないとするこ とができるもので、このことは、コンクリートの破壊が、これまで も指摘されてきたように、引張強度に起因するものであることを示 す。実用的には複合応力下における共通の破壊基準として、Griffi thの破壊基準に支配されるものとして大局的に捉えることができる。 （3）コンクリートと載荷板の摩擦力によって結果が左右され、試驗 体形状による三軸部分圧縮強度の変化は摩擦によって異なることか 判る。解析仮定には、コンクリート供試体と載荷板の摩擦力の効果 が含まれるものて、従来より指摘されているこの摩擦力の王縮強度 に与える影響を考察することができる。

（4）引張強度によって三軸圧縮試験の強度を推定することができる。 また、解析は、Griffithの破壊規準をクラック発生の条件とするく さびの圧入によって、くさび周辺に生じる引張領域が材料にこでは コンクリートの）の引張強度に到達するときに崩壊するとしたもの でり、引張強度のみによって破溒基準を表すものである。三軸圧 縮試験の結果も引張強度から推定が可能となる。

参考文献

1)藤松 進、徳富久二 :コンクリートの破壊条件に関する位相化面 モーメント仮説、日本建築学会論文報告集、第219号、1974 2)德富久二:三軸部分圧縮強度試験による地山シラスの力学的特性、 日本建築学会論文報告集、第370号、1986.12 